\title{
(6) OPEN ACCESS \\ Tobacco endgames: what they are and are not, issues for tobacco control strategic planning and a possible US scenario
}

\author{
Ruth E Malone
}

\begin{abstract}
Correspondence to Professor Ruth Malone, Department of Social and Behavioral Sciences, School of Nursing, University of California, San Francisco, San Francisco, California 94118, USA; ruth.malone@ucsf.edu
\end{abstract}

Received 3 October 2012 Revised 27 November 2012 Accepted 28 November 2012

To cite: Malone RE. Tob Control 2013;22:i42-i44.

\begin{abstract}
Tobacco 'endgame' discourse has emerged in recognition of the nature of the global public health emergency created by tobacco use and tobacco promotion. This discourse is a promising development, but translating it into action requires developing some consensus, at least by countries or regions. It also requires negotiating some of the recurring tensions within the tobacco control movement, contributing to risks for the movement as visionaries clash with pragmatists. This paper outlines one combination of approaches that might hold promise for the US situation. Every significant achievement in tobacco control was preceded by many influential people saying it couldn't be done, wouldn't work, or would create new problems. The risks of not envisioning an endpoint for the tobacco epidemic are far greater than the risks of attempting any endgame solutions and failing.
\end{abstract}

Discussion of a tobacco 'endgame', and the growing body of scholarly research and commentary on how to achieve it, ${ }^{1-21}$ encourage innovative nextgeneration ideas for ending the tobacco epidemic. Yet serious endgame discussion also creates risks. How we respond to these risks will determine what 21 st century tobacco control can accomplish.

An endgame addresses tobacco as a systems issue, rather than an individual behaviour; addresses health and political implications; reframes strategic debates; advances social justice; and is fundamentally transformative in changing how tobacco use and the tobacco industry are regarded. An endgame is not merely more of the same, in that it requires an authentic public policy commitment to achieving a true endgame, as opposed to continuing to envision the public health challenge as an ongoing war of attrition. Incremental change cannot fix this public health emergency, at least not absent a vision of an endpoint when the threat will be eradicated. Thus vision and goals are in some ways more important than specific tactics. What remains astonishing is the degree to which the social construction of tobacco as normal and desirable, accomplished over the last century by a savvy industry, still blinds many to the urgency of our task and the contradictions inherent in our own messages about tobacco.

For example, it becomes more and more impossible to reconcile the 'danger: don't do it' message with tobacco products' ubiquitous availability and legality. The inconsistency with which tobacco is regulated, compared with other far less deadly products, is inexplicable.
Endgame strategies are the means to reach an endpoint. That endpoint should include envisioning the future of tobacco products, tobacco users, the tobacco industry, the role of government and the role of the tobacco control movement. Assuming an endpoint in which death and disease from tobacco would be virtually eliminated, several key questions emerge.

For example, will that envisioned endpoint include no commercially sold tobacco products at all, or only tobacco products less deadly than cigarettes? Or, as some suggest, will only 'clean' nicotine be available commercially? Will tobacco users all have transitioned to other products? Will the tobacco industry still exist as such, or will it focus on other types of nicotine products, as the proliferation of 'alternative' nicotine products suggests is already occurring? Or will the industry move into other businesses? How will we replace government funds generated through tobacco taxes, when the savings from reduced rates of death and disease may be unrealised for decades? Will there still be a tobacco control movement at the endpoint?

Even if we find consensus, our ability to rationally and methodically plot a route to the endpoint is limited. Policy literature ${ }^{22-25}$ demonstrates that social change results from multiple factors, many serendipitous and unpredictable. The point is to be ready-to believe it is possible to permanently change what tobacco means in our societies, and to talk about it openly.

At least three tensions must be navigated. First, should transitions be gradual or abrupt? Abrupt change makes it more difficult for the tobacco industry to adapt and thereby reduce a policy's effectiveness. However, abrupt change can also create public anxiety and increase resistance.

Another tension is whether public health should compete or cooperate with the tobacco industry. The industry has no wish to kill people; it simply wants to make money. Massive death is simply an accepted externality of doing business. Incentivise that business differently, goes this argument, and the industry may become part of the solution. Others, notably those concerned with implementation of Article 5.3 of the WHO Framework Convention on Tobacco Control, ${ }^{26}$ which seeks to protect public health policy from tobacco industry interference, assert that the industry in many respects is the tobacco problem. A true endgame scenario must ultimately end commercial promotion of tobacco products. These might be characterised as accommodationist versus abolitionist perspectives. 
Third, how harmful is nicotine addiction in the absence of smoking? Is our endpoint reached when we have eliminated use of combustible commercial tobacco, or tobacco in any form? Are incentives to move addicted tobacco users toward medicinal or other forms of 'clean' nicotine the means to an end, or the end in itself? Some suggest the latter. Yet there is considerable evidence that nicotine is not benign, but may play a critical role in disrupting cell regulation and cell-mediated immune function, ${ }^{27}$ and that even products considered far less harmful than smoked tobacco, such as Swedish snus, are associated with elevated death rates from cancers. ${ }^{28}$ The complexity of addiction means that this is also not merely a question of biochemistry. Should we encourage use of products such as e-cigarettes that powerfully model smoking behaviour but presumably expose users to fewer dangerous compounds?

The risks of not envisioning an endpoint are clearly far greater than the risks of attempting any of these solutions and failing. In the USA, it is hard to imagine that trying and failing at any endgame could result in nearly 400000 deaths a year. Any endpoint will only come after many years of paying the price for current failures to respond more aggressively to this epidemic. But it is worth tackling radical ideas, because even short-term failures may contribute to achieving long-term goals: witness the first attempts in California to achieve smoking sections in restaurants, which failed-but which initiated a public conversation that eventually led to $100 \%$ smoke-free spaces. ${ }^{29}$ Thus we should not too quickly foreclose conversations about more radical endgame strategies, even if they do not at first succeed.

Different solutions will prove possible in different places, and may unfold in unique ways. In Singapore, Finland and the Australian state of Tasmania, for example, there is serious discussion of implementing a law banning cigarette sales to those born after a particular year, usually 2000 (see elsewhere in this issue). ${ }^{30}$ I believe that all endgame approaches would require continuing, explicit and aggressive industry denormalisation ${ }^{31}$ to enhance existing measures and accompany product modifications, limits on retail outlets, and an eventual phasing out of cigarettes from the market.

In the US, where regulatory regimes are more stubbornly incrementalist, an effective endgame will likely involve combining approaches across different levels of government, as I outline here in brief. Initially, I would focus on the cigarette alone, as the single most deadly tobacco product. Nationally, the US Food and Drug Administration (FDA) could require lower nicotine levels in all cigarettes, reducing their addictiveness, and ensure that any restrictions on conventional cigarettes apply to quasi-cigarette products such as little cigars. This is feasible, within the mandate of the FDA, and as discussed elsewhere in this issue, evidence suggests that it might make it easier for smokers to quit and would not lead to compensatory smoking. Further restricting the marketing of other products could help reduce dual use and youth uptake-again, measures that lie within the federal purview.

US states could restrict tobacco outlets, either through first limiting cigarette sales to state-run outlets, as some states now manage 'hard' alcohol, or by capping the number of retail outlets within a geographic area. Again, this is feasible and there are models on which such a system could be constructed. Display bans could reduce visual cues that elicit purchase. The goal, however, should be to move toward phasing commercial cigarettes off the market, with reasonable advance notice. No other product that killed half its normal users would be permitted on the market today; it is simply unacceptable to allow the current situation to continue.
Cities and towns could initiate the first cigarette sales bans, just as they led on secondhand smoke policies, but they would have to anticipate industry litigation. In some ways, however, even if they passed such measures and then could not afford to fight the subsequent lawsuits, the media coverage of the issue in town after town could advance the goals of tobacco control by keeping the industry in the news fighting against local public health initiatives.

There are ample arguments to explain why all this won't work. But every single effective tobacco control policy ever proposed was initially met with scepticism. When people in Richmond, California sought smoke-free air in their apartment complexes, proponents were told it couldn't be done. When flight attendants wanted smoke-free airplanes, they were told that smokers would riot and planes would crash. When advocates sought smoke-free Irish bars and pubs, their own colleagues scoffed. But the seemingly impossible happened in all these places.

It happened because someone imagined it could, and kept talking about it.

Acknowledgements I value the ongoing endgame conversations with colleagues in my research group: Valerie Yerger, Elizabeth Smith, Naphtali Offen, Patricia McDaniel and Vera Harrell, as well as many colleagues globally, some of whose work is represented elsewhere in this supplement.

Contributors REM conceived and wrote the paper.

Competing interests REM owns one share each of Philip Morris/Altria, Philip Morris International and Reynolds American tobacco company stock for research and advocacy purposes. She served as a tobacco industry documents consultant for the US Department of Justice in USA vs Philip Morris et al.

Provenance and peer review Not commissioned; externally peer reviewed.

Open Access This is an Open Access article distributed in accordance with the Creative Commons Attribution Non Commercial (CC BY-NC 3.0) license, which permits others to distribute, remix, adapt, build upon this work non-commercially, and license their derivative works on different terms, provided the original work is properly cited and the use is non-commercial. See: http://creativecommons.org/ licenses/by-nc/3.0/

\section{REFERENCES}

1 Callard C, Thompson D, Collishaw N. Transforming the tobacco market: why the supply of cigarettes should be transferred from for-profit corporations to non-profit enterprises with a public health mandate. Tob Control 2005;14:278-83.

2 Khoo D, Heng-Nung Koong H-N, Berrick AJ, et al. Phasing-out tobacco: proposal to deny access to tobacco for those born from 2000. Tob Control 2010;19:355-60.

3 Borland R. A strategy for controlling the marketing of tobacco products: a regulated market model. Tob Control 2003;12:374-82.

4 Malone RE. Imagining things otherwise: new endgame ideas for tobacco control. Tob Control 2010;19:349-50.

5 Daynard RA. Doing the unthinkable (and saving millions of lives). Tob Control 2009;18:5.

6 Hall WD, West R. Thinking about the unthinkable: a de facto prohibition on smoked tobacco products. Addiction 2008;103:873-4.

7 Gartner C, McNeill A. Options for global tobacco control beyond the framework convention in tobacco control. Addiction 2010;105:1-3.

8 Chapman S, Liberman J. Ensuring smokers are adequately informed: reflections on consumer rights, manufacturer responsibilities, and policy implications. Tob Control 2005;14(Suppl2):ii8-13.

9 Benowitz NL, Henningfield JE. Establishing a nicotine threshold for addiction-the implications for tobacco regulation. N Engl J Med 1994;331:123-5.

10 Hatsukami DK, Perkins KA, LeSage $M$, et al. Nicotine reduction revisited: science and future directions. Tob Control 2010;19:e1. doi:10.1136/tc.2009.035584

11 Laugesen M, Glover M, Fraser T, et al. Four policies to end the sale of cigarettes and smoking tobacco in New Zealand by 2020. N Z Med J 2010;123:55-67.

12 Gilmore $A B$, Branston JR, Sweanor D. The case for OFSMOKE: how tobacco price regulation is needed to promote the health of markets, government revenue and the public. Tob Control 2010;19:423-30

13 Thomson G, Wilson N, Blakely $\mathrm{T}$, et al. Ending appreciable tobacco use in a nation: using a sinking lid on supply. Tob Control 2010;19:431-35.

14 Thomson G, Wilson N, Edwards R. Kiwi support for the end of tobacco sales: New Zealand governments lag behind public support for advanced tobacco control policies. N Z Med J 2010;123:106-11. 
15 Wilson N, Edwards R, Thomson G, et al. High support for a tobacco endgame by Pacific peoples who smoke: national survey data. N Z Med J 2010;123:131-4.

16 Maubach N, Hoek JA, Edwards R, et al. 'The times are changing': New Zealand smokers' perceptions of the tobacco endgame. Tob Control 2012; Published Online First: 16 June 2012. doi:10.1136/tobaccocontrol-2011-050398.

17 Borland R. The need for new strategies to combat the epidemic of smoking-related harm. Tob Control 2012:21:287-8.

18 Callard CD, Collishaw N. Exploring vector space: overcoming resistance to direct control of the tobacco industry. Tob Control 2012;21:291-2.

19 Thomson $\mathrm{G}$, Edwards $\mathrm{R}$, Wilson $\mathrm{N}$, et al. What are the elements of the tobacco endgame? Tob Control 2012;21:293-5.

20 Edwards R, Peace J, Russell M, et al. Qualitative exploration of public and smoker understanding of, and reactions to, an endgame solution to the tobacco epidemic. BMC Public Health 2012:12:782

21 McDaniel PA, Malone RE. "The Big WHY": Philip Morris's failed search for corporate social value. Am J Public Health 2012;102:1942-50

22 Kingdon JW. Agendas, alternatives, and public policies. 2nd edn. New York: Longman/Addison Wesley, 1995.

23 Schneider JW. Social problems theory: the constructionist view. Annu Rev Sociol 1985;11:209-29.
24 Stone D. Policy paradox: the art of political decision making. New York: Norton, 1997.

25 Stone DA. Causal stories and the formation of policy agendas. Political Sci Q 1989:104:281-300.

26 World Health Organization. WHO framework convention on tobacco control guidelines for implementation art.5.3, art. 8, arts. 9 \& 10, art. 11, art. 12, art. 13, art. 14. Geneva. World Health Organization, 2011.

27 Cardinale A, Nastrucci C, Cesario A, et al. Nicotine: specific role in angiogenesis, proliferation and apoptosis. Crit Rev Toxicol 2012;42:68-89.

28 Nordenvall C, Nilsson PJ, Ye W, et al. Tobacco use and cancer survival: a cohort study of 40,230 Swedish male construction workers with incident cancer. Int J Cancer 2013;132:155-61.

29 Glantz SA, Balbach ED. Tobacco war: inside the California battles. Berkeley: University of California Press, 2000.

30 Ghosh PR. Tasmania Seeks To Create Tobacco-Free Generation By Banning Cigarette Sales To Anyone Born After 2000. International Business Times http://wwwibtimescom/tasmania-seeks-create-tobacco-free-generation-banningcigarette-sales-anyone-born-after-2000-752901 (accessed 21 Nov 2012).

31 Malone RE, Grundy Q, Bero LA. Tobacco industry denormalisation as a tobacco control intervention: a review. Tob Control 2012:21:162-70. 